\title{
Knowledge Exchange in the Canadian Wood Fibre Centre: National scope with regional delivery
}

\author{
by Steve D'Eon ${ }^{1}$ and Katalijn MacAfee ${ }^{1, *}$
}

\begin{abstract}
Since its inception in 2006, the Canadian Wood Fibre Centre (CWFC), a branch of Natural Resources Canada's Canadian Forest Service, has placed an emphasis on Knowledge Exchange (KE). KE at the CWFC has followed a progression from raising awareness, to generating interest, through to providing support for those deciding to adopt an innovation. Designing a program of national scope with regional delivery has led the CWFC to partner with different regional delivery organizations. Across Canada, Light Detection and Ranging (LiDAR) based Enhanced Forest Inventory has become a very successful innovation spearheaded by the CWFC in partnership with academia, the forest industry, and a growing consulting sector. The KE program for LiDAR based Enhanced Forest Inventory is used as an example to illustrate the CWFC's KE methods along with a description of regional delivery agencies and the success in getting this innovation adopted.
\end{abstract}

Keywords: knowledge exchange, LiDAR, enhanced forest inventory

\section{RÉSUMÉ}

Depuis sa création en 2006, le Centre canadien sur la fibre de bois (CCFB), une direction générale du Service canadien des forêts au sein de Ressources naturelles Canada, a mis laccent sur les échanges de connaissances (EC). L'EC au CCFB a connu une progression importante passant de la sensibilisation à l'apparition d'un intérêt, grâce à l'aide fournie aux décideurs responsables d'adopter l'innovation. En créant un programme national tout en agissant au niveau local, le CCFB a établi des partenariats avec différents organismes livreurs régionaux. Dans lensemble du Canada, les inventaires forestiers améliorés à l'aide du Lidar (détection et télémétrie par ondes lumineuses) représentent une innovation très remarquée pilotée par le CCFB en partenariat avec les universités, lindustrie forestière et un secteur de la consultation de plus en plus important. Le programme des EC pour les inventaires forestiers améliorés à laide du Lidar sert à illustrer les méthodes d'EC du CCFB de même quà décrire les organismes responsables régionaux de livraison et le succès obtenu pour faire adopter cette innovation.

Mots clés : échange de connaissances, LiDAR, inventaire forestier amélioré

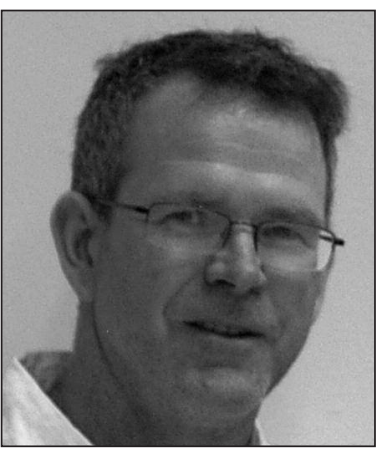

Steve D'Eon

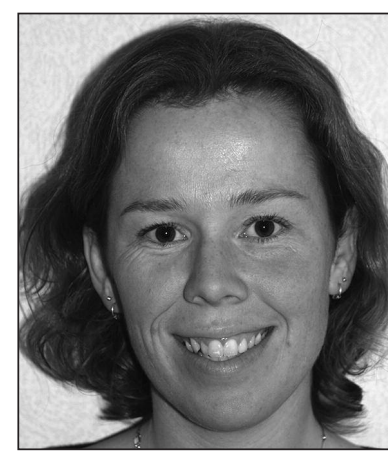

Katalijn MacAfee

\section{Introduction}

Canada's forests stretch east-west across the continent from the Atlantic to the Pacific oceans and from the southern border with the United States to the northern tree line in the Artic. The vast majority of Canada's 200 million ha of productive forest is owned by the provinces, whereas the federal gov- ernment's role focuses on international trade, policy, and research. Within its research vein, Natural Resources Canada (NRCan) recognized the need for better integration between its forestry section, the Canadian Forest Service (CFS), and forest industry as a way to keep the Canadian forest sector innovative, sustainable, and competitive.

In response to this need, a new branch of the CFS was formed in 2006, the Canadian Wood Fibre Centre (CWFC). The CWFC was established without responsibility for infrastructure as a 'virtual institute' housed in eight different CFS research facilities (CWFC 2007). At the same time, the Canadian forest sector's industrial research organizations FERIC, Forintek, and Paprican merged to become FPInnovations. The CWFC and FPInnovations were also formally linked to create the largest forest research organization in Canada. This unofficial public-private partnership provided a link to innovative research solutions across the entire forest value chain, from genetically improved seedlings through to value-added consumer products. Merging the long-term ecological nature of CFS research with the more short-term applied research industry needs created a government branch that is nimble,

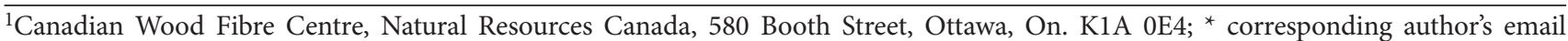
katalijn.macafee@canada.ca 
flexible, efficient, and focused on delivering adoptable solutions for real-world problems faced by the sector. Close ties to the industry-focused FPInnovations has allowed CFS to bridge the gap between research and implementation.

\section{Knowledge Exchange within the CWFC}

When the Canadian Wood Fibre Centre was launched, CFS brought George Bruemmer on board as the new Executive Director. Mr. Bruemmer had led the Forestry Research Partnership (FRP) in Ontario very successfully and recognized that uptake and application of CWFC research would have to be facilitated by a culture and commitment to Knowledge Exchange (KE) throughout the organization (Bruemmer 2008, Smith et al. 2008).

Another aspect recognized early on was that success in $\mathrm{KE}$ would greatly increase by working closely with valued partners. One logical partner was FPInnovations and a joint CWFC and FPInnovations Knowledge Exchange Team was formed. Collaboration is on-going with regular team meetings, joint projects, and coordinated efforts. A more recent joint $\mathrm{KE}$ effort has been undertaken with the KE team from the CFS. With many research projects becoming cross-cutting between the CFS, the CWFC, and FPInnovations, these KE partnerships are valuable tools in efficiently delivering robust and adoptable innovations to the Canadian forest sector.

Other long-term KE partnerships continue with the Canadian Institute of Forestry (both their national office and Section offices), the Canadian Woodlands Forum (CWF) in Atlantic Canada, and Partenariat Innovation Forêt (PIF) in Quebec. To effectively implement its strategy, the CWFC also works with provincial professional associations, provincial forestry and/or natural resource departments, academia, and industrial partners. Regional partners bring local credibility, knowledge of important regional players and client base, use local terminology, respect local issues, and understand local ownership, management, and priorities. The CWFC's national and regional partners are essential to the success of KE.

One of the challenges, or perhaps benefits, at the CWFC is that research programs with both national research projects as well as more regionally focused projects all require management. Using a strategy of national program scope with regional delivery has served the CWFC's KE needs well in a forest sector that spans six time zones, two official languages, and countless ecological and business landscapes.

\section{KE techniques used at the CWFC}

The CWFC has always followed a well-documented progression towards adoption in its KE program. First, the breadth and depth of an innovation (or research component) are evaluated in order to identify the suitable market and potential end users. Breadth estimates how much land base or implementation base to which an innovation will apply. For example, an innovation that provides solutions for a tree species of national magnitude, such as white spruce, will have greater breadth than an innovation aimed at a tree species that grows in only one region of Canada such as black walnut. Depth refers to the degree the innovation will be used in terms of frequency, importance, and impact. For example, an innovation that alters a process and offers a one-time cost saving of a few dollars per process has less depth than an innovation that will alter a repeating process that is used hourly with a transformative impact. The combination of breadth and depth provides an estimate of the potential importance of the innovation to the forest sector. Secondly, the KE program evaluates whether an innovation is a 'push', a 'pull', or a 'drag. A 'push' is an innovation that has not been requested and must be pushed upon end-users in order for them to recognize the benefits. A 'pull' is an innovation that fills a previously requested demand and has an existing market. A 'drag' is a regulatory requirement that the forest sector must meet and demand for the innovation is contingent upon the regulations remaining in place.

Rogers (2003) described five stages in the innovation-decision process: knowledge, persuasion, decision, implementation, and confirmation. Ahlander (1990) described four steps in the adoption process, calling the process a "stairway to change". The CWFC uses a five stage progression from discovery/research to support for adopters (Table 1). Feedback throughout the process improves the innovation. The CWFC progression is not implemented in a linear fashion as regions may be at different stages, and within a region there may be early adopters looking ahead, more cautious enterprises closely following the innovation's progress, and late adopters only monitoring the uptake before considering their situation. Flexibility is a key component in the CWFC KE program, but the general progression from discovery/research stage to adopting stage remains an integral part of CWFC KE planning.

\section{KE products used by the CWFC}

Implementing a successful KE program involves more than establishing the right partnerships and creating a culture of $\mathrm{KE}$ within an organization. The right KE tools have to be used at the right time to engage the right audiences. The CWFC carefully evaluates and uses limited resources, wisely matching the proper KE tool to the stage of adoption a target audience is at. As well, some innovations lend themselves better to certain KE products than others. Quite often a combination of tools delivered in sequence can be extremely valuable, for instance releasing a best practices guide and then following up six months later with an electronic lecture. Engaging CWFC researchers in delivering these high quality KE products is a continuous commitment and essential for their effectiveness and ultimately their success.

The CWFC uses many KE products including traditional hard copy publications, web-based learning products, in-person presentations, and more modern virtual field tours and complete tool kits (Table 2). CWFC research is often collaborative with multiple partners and CWFC KE events normally include a diversity of presenters from different organizations with multiple co-authors. Most CWFC KE efforts do not exclusively present CWFC research and tend to present nonCWFC research results within the same theme. In many cases the CWFC searches for the ideal partner to deliver a KE product and may provide direct financial support, logistical support, speakers or presenters, or participate in organizing the event. Partners are quite often better positioned to deliver a KE product and the CWFC is quite willing to support their complimentary efforts (MacAfee 2015). 
Table 1. Overview of the CWFC KE progression

\begin{tabular}{|c|c|c|c|c|}
\hline Adoption Stage & Tone & Audience & Goal & Products \\
\hline Discovery/Research & Prove it & $\begin{array}{l}\text { Other scientist, } \\
\text { researchers, } \\
\text { research managers }\end{array}$ & $\begin{array}{c}\text { Ensure the science } \\
\text { is valid }\end{array}$ & $\begin{array}{l}\text { Scientific papers, } \\
\text { Conferences, } \\
\text { Symposiums, } \\
\text { Posters }\end{array}$ \\
\hline $\begin{array}{l}\text { Raising Awareness } \\
\text { Pass along knowledge }\end{array}$ & Tell me & Mass & $\begin{array}{l}\text { Inform potential } \\
\text { users of the innovation }\end{array}$ & $\begin{array}{c}\text { Field Days, } \\
\text { Demonstrations, } \\
\text { General Presentations, } \\
\text { Electronic lectures, } \\
\text { Webinars, } \\
\text { Brief web pages, } \\
\text { Papers in general literature. }\end{array}$ \\
\hline $\begin{array}{l}\text { Generating Interest } \\
\text { Persuade potential users }\end{array}$ & Show me & Group & $\begin{array}{l}\text { Generate interest } \\
\text { in adopting the } \\
\text { innovation }\end{array}$ & $\begin{array}{c}\text { Workshops, } \\
\text { Demonstration Areas, } \\
\text { Electronic lectures, Webinars, } \\
\text { Technical notes, } \\
\text { Professional papers, } \\
\text { Articles in trade magazines. }\end{array}$ \\
\hline $\begin{array}{l}\text { Support for Decision } \\
\text { Help them estimate } \\
\text { their situation }\end{array}$ & Help me decide & $\begin{array}{l}\text { Individual } \\
\text { corporate }\end{array}$ & $\begin{array}{l}\text { Support those } \\
\text { contemplating } \\
\text { adoption }\end{array}$ & $\begin{array}{l}\text { Synthesis Reports, } \\
\text { Compendium of results, } \\
\text { Economic reports, } \\
\text { Reports on those who } \\
\text { have adopted, } \\
\text { Case studies. }\end{array}$ \\
\hline $\begin{array}{l}\text { Support for Adopters } \\
\text { Instruct how to do it }\end{array}$ & Instruct me & $\begin{array}{l}\text { Individual } \\
\text { one on one }\end{array}$ & Support those adopting & $\begin{array}{l}\text { Field Guides, Manuals, } \\
\text { Video instructions, } \\
\text { 1-800 numbers, } \\
\text { Best practices guides. }\end{array}$ \\
\hline
\end{tabular}

A CWFC KE success story: Enhanced Forest Inventory Research in Enhanced Forest Inventory (EFI) has been a multi-partner effort to tackle one of Canada's long-standing forest management problems-providing an accurate and precise forest inventory on a forest manager's desktop (Wulder et al. 2008, Pitt and Pineau 2009, Woods et al. 2011). EFI uses airborne data collected using Light Detection and Ranging (LiDAR) which provides a computerized three-dimensional view of the ground (a digital terrain map) and morphological characteristics of trees including their crown shape and tree height. Detailed measurements of individual trees from ground plots and digital air photos complete the components used in EFI. The tree measurements are precisely lined up with the LiDAR-derived tree characteristics from which models are developed and applied across the land base.

EFI places on a forest manager's desktop a comprehensive inventory of statistically validated estimates of forest characteristics of interest for the entire land base under management (Woods et al. 2011). It provides forest managers with precise information on what is where and how to get there so that they can plan the best way to sustainably manage the forest.

One measure of success for an innovation is on how many hectares of forest land the innovation has been applied, and the breadth of the application. By early 2015, EFI had been cre- ated and used on over five million ha in Canada, while LiDAR had been collected for 25 to 30 million ha, with an additional 50 million ha in the planning stage (D'Eon 2015). It is estimated by the end of the 2016 season half of Canada's managed forest will either have, be producing, or be planning to collect LiDAR capable of creating an Enhanced Forest Inventory.

Users of the technology found they used EFI for twice the number of applications they expected and this formed a basis for their business case to purchase the technology (D'Eon et al. 2015). James D. Irving described the technology to the House of Commons Standing Committee on Natural Resources with this statement: "It's a Game-Changer" (Parliament of Canada 2015). An early report by the U.S. Forest Service (USFS) provided a favourable comparison of the costs-benefits of a LiDAR-based inventory versus a traditional inventory for annual sampling in a 500000 ha evenaged managed forest, reporting time savings of $28 \%$ and dollar savings of $45 \%$ (Renslow et al. 2000). A 2011 study by the USFS in Oregon on an operational implementation of LiDAR-based EFI concluded it was cost competitive compared to traditional methods for areas of 20000 ha and greater (Hummel et al. 2011). The State of Maine has reported a benefit to cost ratio of 4:1 with a payback of 2.3 years for all uses within a State sponsored LiDAR acquisition (Carswell 
Table 2. Various CWFC led KE products and their benefits

\begin{tabular}{|c|c|c|c|c|}
\hline KE product & Effort/ Cost ${ }^{1}$ & Audience & Distribution $^{2}$ & Benefits \\
\hline $\begin{array}{l}\text { Special edition of a } \\
\text { practitioner journal } \\
\text { such as The Forestry } \\
\text { Chronicle }\end{array}$ & $\begin{array}{l}\text { Very } \\
\text { High } \\
\$ \$ \$\end{array}$ & $\begin{array}{l}\text { Practitioners, managers, } \\
\text { scientists }\end{array}$ & Subscribers plus libraries. & $\begin{array}{l}\text { Reaches a broad targeted } \\
\text { audience with detailed content. } \\
\text { Journals have a very long shelf life. }\end{array}$ \\
\hline $\begin{array}{l}\text { Article in a trade } \\
\text { magazine such as } \\
\text { Logging and Sawmilling }\end{array}$ & $\begin{array}{c}\text { Low } \\
\$\end{array}$ & $\begin{array}{l}\text { Industry, managers, } \\
\text { practitioners. }\end{array}$ & $\begin{array}{l}\text { Subscribers plus website } \\
\text { downloads. }\end{array}$ & $\begin{array}{l}\text { Reaches a targeted audience with } \\
\text { summary information. } \\
\text { Medium shelf life. }\end{array}$ \\
\hline $\begin{array}{l}\text { CFS Technical Note } \\
\text { such as Fibre Facts }\end{array}$ & $\underset{\$}{\text { Medium }}$ & Industry, practitioners. & $\begin{array}{l}\text { Open, unlimited downloads } \\
\text { from CFS Bookstore. }\end{array}$ & $\begin{array}{l}\text { Good vehicle for raising awareness } \\
\text { or providing more detailed content. } \\
\text { Medium shelf life. }\end{array}$ \\
\hline $\begin{array}{l}\text { CFS Information } \\
\text { Reports }\end{array}$ & $\begin{array}{l}\text { High } \\
\$\end{array}$ & $\begin{array}{l}\text { Practitioners, managers, } \\
\text { scientists }\end{array}$ & $\begin{array}{l}\text { Open, unlimited downloads } \\
\text { from CFS Bookstore. }\end{array}$ & $\begin{array}{l}\text { Good vehicle for providing detailed } \\
\text { content such as case studies. } \\
\text { Good shelf life. }\end{array}$ \\
\hline Electronic Lecture & $\underset{\$}{\text { Medium }}$ & Very broad & $\begin{array}{l}\text { Open. Typically } 400 \text { to } \\
700 \text { participants }\end{array}$ & $\begin{array}{l}\text { Good vehicle for generating } \\
\text { interest. Very short shelf life. }\end{array}$ \\
\hline $\begin{array}{l}\text { Short one or two-day } \\
\text { workshops }\end{array}$ & $\begin{array}{l}\text { Low to } \\
\text { Medium } \\
\$ \text { to } \$ \$\end{array}$ & $\begin{array}{l}\text { Local to regional; } \\
\text { targeted to general. }\end{array}$ & 20 to 200 , Limited & $\begin{array}{l}\text { Can provide detail and interactions } \\
\text { with the audience. Can be instruc- } \\
\text { tive. }\end{array}$ \\
\hline Field days/tours & $\begin{array}{l}\text { Low to } \\
\text { High } \\
\$ \text { to } \$ \$\end{array}$ & Local, targeted. & 10 to 100 , Limited & $\begin{array}{l}\text { Very good learning experience for } \\
\text { the audience. }\end{array}$ \\
\hline Virtual tours & $\underset{\$ \$}{\text { High }}$ & Local to regional, broad. & Open, unlimited. & $\begin{array}{l}\text { Most of the experience of a field day } \\
\text { without the audience travelling. }\end{array}$ \\
\hline Best Practices Guides & $\begin{array}{l}\text { High } \\
\$\end{array}$ & $\begin{array}{l}\text { Targeted to those } \\
\text { deciding to adopt. }\end{array}$ & Depends upon the publisher. & $\begin{array}{l}\text { Instructional. Important for those } \\
\text { at the decision to adopt stage. }\end{array}$ \\
\hline Took kits & $\begin{array}{l}\text { Very High } \\
\quad \$ \$ \$\end{array}$ & $\begin{array}{l}\text { Local to regional. } \\
\text { Targeted to those } \\
\text { deciding to adopt. }\end{array}$ & Open, unlimited. & $\begin{array}{l}\text { Instructional. Important for those } \\
\text { at the decision to adopt stage. }\end{array}$ \\
\hline
\end{tabular}

${ }^{1}$ Effort refers to the resources required to create the product. Cost refers to typical direct costs to the CWFC excluding translation. $\$=\$ 0$ to $\$ 1000, \$ \$=\$ 1000$ to $\$ 10000, \$ \$ \$=>\$ 10000$.

${ }^{2}$ Printing and distribution of hard copies for CFS publications are evaluated on a case by case basis and not included in this table.

2014). Forest resource management was ranked as the third greatest benefit. An Australian study in a 250000 ha forest showed positive cash flow after two years and a five-year total NPV of AU \$1.4 million (Brown and Sutton 2012).

Despite these documented benefits, EFI did not sell itself. LiDAR and EFI were viewed as an expensive alternative to traditional methods (Lacroix and Charette 2013). Forest industry perceived inventory as provincial responsibility. From a KE perspective, EFI does not have features that make it easily adopted: EFI is difficult to test on a trial basis, as collecting airborne LiDAR is price-prohibitive per ha for smaller areas and rapidly comes down in price as the area surveyed increases. Furthermore, the technology does not layer onto existing forest inventories but instead replaces them, and the skill required to build and operate an EFI are usually not found in-house in a forest company.

To overcome these barriers and others, the CWFC adopted a partnered plan in 2011 to raise awareness, generate interest, and support the decision to adopt LiDAR and EFI
(Table 3).With a culture of KE embedded in the CWFC, the KE program benefited from researchers being willing and active participants in presenting EFI to audiences from coast to coast. The research program also found industrial partners in four separate regions to undertake management-unit scale EFIs as 'flagship' sites. The flagship sites served as proving grounds for implementing the technology, refining the research, and generating results others could perceive as relevant to their situation.

During the early phases, KE efforts focused on presentations at workshops, forums, tradeshows, seminars, and conferences, making 114 presentations compared to producing 27 reports (Bruemmer 2012). The KE program set its goal that every working forester in the country would have heard of the program in two years. To test this assumption, in 2012 the CWFC along with FPInnovations undertook a limited informal survey of 76 companies and provincial agencies and found that all respondents had heard of the technology (D'Eon and Kurowski 2012). More than half of the respon- 
Table 3. Overview of the 2011 adoption plan for the enhanced forest inventory program

\begin{tabular}{|c|c|c|c|c|}
\hline $\begin{array}{l}\text { Adoption Stage } \\
\text { and time frame }\end{array}$ & $\begin{array}{l}\text { Research, trial } \\
\text { pre } 2011\end{array}$ & $\begin{array}{l}\text { Roll out } \\
2012-2013\end{array}$ & $\begin{array}{c}\text { Peak adoption effort } \\
2012-2014\end{array}$ & Update 2014 \\
\hline Discovery & \multicolumn{4}{|c|}{ 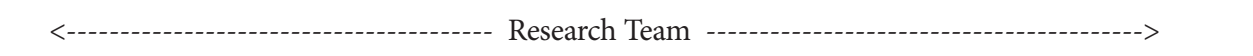 } \\
\hline Raise awareness & $\begin{array}{l}\text { Research team, } \\
\text { CWFC KE team }\end{array}$ & $\begin{array}{l}\text { Research team, } \\
\text { CIF/CWFC/FPI KE team }\end{array}$ & - & - \\
\hline Generate interest & - & $\begin{array}{l}\text { Research team, } \\
\text { CIF/CWFC/FPI KE team }\end{array}$ & $\begin{array}{l}\text { Research team, } \\
\text { KE team }\end{array}$ & - \\
\hline Support the decision to adopt & - & - & $\begin{array}{l}\text { Research team, } \\
\text { CWFC/FPI KE team, } \\
\text { technical specialists }\end{array}$ & $\begin{array}{l}\text { KE team, technical } \\
\text { specialists }\end{array}$ \\
\hline Technical support for adopters & - & - & $\begin{array}{l}\text { FPInnovations, } \\
\text { Consultants }\end{array}$ & $\begin{array}{l}\text { FPInnovations, } \\
\text { Consultants }\end{array}$ \\
\hline
\end{tabular}

dents were interested but not yet moving towards adopting the technology, and only $11 \%$ were in the process of evaluating whether to adopt the technology or not. In response, the KE program reduced emphasis on raising awareness and increased emphasis on case studies and workshops presenting peer-to-peer regionally applicable results. Between 2012 and 2014 dedicated workshops were hosted across the country by various partners, including PIF in Quebec, CWF in Atlantic Canada, and the CIF/IFC in every province except Nova Scotia and PEI.

As interest grew, the KE program switched to overcoming specific issues such as the perception that EFI was costly. Demonstration sites and impact notes described the technology and the benefits flowing from the flagship partners (Wang et al. 2012). On occasion results were analyzed for a specific target audience to present real costs directly applicable to the audience (D'Eon 2013). To assist broadly in the decision to adopt, the KE program funded a suite of regional workshops hosted by the CIF/IFC with the University of British Columbia and FPInnovations that provided hands-on training to ease the concern that the technology was difficult to use. The CFS published a best practices guide to clearly document the methods used (White et al. 2013). This guide was supplemented with an electronic lecture hosted by the CIF/IFC that was the most attended e-lecture in the Institute's history of electronic lectures with 675 participants (Meade 2014).

In 2014, the CWFC in collaboration with the CIF/IFC conducted a broader email survey from a contact list of over 1000 and found a very high satisfaction rate amongst adopters (FPInnovations 2015), yet the perception of high costs remained with those not using the technology (D'Eon et al. 2015). Again adjustments were made to the KE program in response to the user community needs with an emphasis on actual costs and real world applications (Kurowski and D'Eon 2015, Pitt 2016, Vekeman 2016). As adoption became heavily embedded in some regions, the KE program relied upon users telling their stories, such as Tembec in Ontario (Bernier 2015), J.D. Irving Ltd. in New Brunswick (Dick 2013, Pitt 2015), or Corner Brook Pulp and Paper in Newfoundland (Moulton 2013). EFI suppliers started advertising their services and providing training (Côté-DeMerchant 2016).

\section{Conclusions}

From its inception, the CWFC has strongly supported a meaningful and comprehensive KE program. The process guides an innovation or research outcome from the discovery stage, through creating awareness and raising interest, to providing support for the decision to adopt. The CWFC uses various KE products tailored towards specific audiences and with targeted benefits. The CWFC also recognizes the strength of using partners and collaborators. The CWFC KE Program is seen as the cream of the crop within the CFS when it comes to $\mathrm{KE}$, and this is partly due to the relationship with its partners. Since 2006 the CWFC KE program for Enhanced Forest Inventory has evolved and used appropriate partners to provide KE product users needed to progress towards their decision to adopt. Adoption, judged by hectares where the innovation is applied or in the process of being applied, confirms the program's success.

\section{References}

Ahlander, R. 1990. Some good advice for advisors. Nat. Board of Forestry, Sweden.

Bernier, J-L. 2015. Tech Advantage. Can. For. Indust. Nov./Dec. 2014. Bruemmer, G. 2008. The Forestry Research Partnership: Developing the partnership. Forest. Chron. 84(5): 648-652.

Bruemmer, G. 2012. Canadian Wood Fibre Centre [online]. Green Fibre Network, Cornwall, ON, May 2, 2012. Available from: http://www.greenfibrenetwork.ca/wp-content/uploads/2011/06/1.George-Bruemmer-Keynote. pdf [accessed June 16, 2016].

Brown, T. and M. Sutton. 2012. Demonstrations of a successful LiDAR business case -conception to reality. In Silvilaser2012.Com Full Proceedings, Vancouver, B.C. Sept. 16-19, 2012. Available from: http://silvilaser2012.com/wp-content/uploads/2011/11/Silvilaser2012_Full_Proceedings.pdf [accessed June 16, 2016].

CWFC. 2007. (Canadian Wood Fibre Centre). Development Plan 2006-2009. Nat. Res. Can., Ottawa, On.

Carswell, W.J., Jr. 2014. The 3D elevation program-summary for Maine. U.S. Geological Survey Fact Sheet 2014-3013.http:// dx.doi.org/10.3133/fs20143013.

Côté-DeMerchant, R. 2016. LiDAR EFI: The evolution from research to application [online]. Canadian Woodlands Forum, Moncton, NB. Apr 2016. Available from: ttp://cwfcof.org/wpcontent/uploads/2015/10/2016-SM-Preliminary-Program-web.pdf [accessed on June 16, 2016]. 
D'Eon, S. 2013. Enhanced forest inventory: A valuable tool for standing timber sales. Logging and Sawmilling J. June/July 2013.

D'Eon, S. 2015. Better, faster, cheaper: Airborne LiDAR and enhanced forest inventory taking off across Canada. Logging and Sawmilling J. Nov. 2015.

D'Eon, S. and M. Kurowski. 2012. National assessment of ALiDAR and enhanced forest inventory adoption in Canada. NRCan internal report.

D'Eon, S., Meade, M. and M. Kurowski. 2015. Survey reveals expanding use of A-LiDAR and enhanced forest inventory technologies. Logging and Sawmilling J. May 2015.

Dick, A. 2013. LiDAR project at the Acadia Research Forest [online]. NHRI LiDAR Seminar - Edmundston NB, May, 2013. Available from: http://www.irfn-nhri.org/en/component/phoca download/category/12-seminaire-lidar-lidar-seminar[accessed on June 16, 2016].

FPInnovations. 2015. LiDAR-based enhanced forest inventory users express $97 \%$ satisfaction rate. FPSolutions. Forest Operations, Other news, May, 2015.

Hummel, S., A.T. Hudak, E.H. Uebler, M.J. Falkowski and K.A. Megown. 2011. A comparison of accuracy and cost of LiDAR versus stand exam data for landscape management on the Malheur National Forest. J. For. 109(5): 267-273.

Kurowski, M. and S. D'Eon. 2015. Adopting LiDAR in forest operations: Costs, benefits, and management decisions. FPInnovations Knowledge Exchange Group Webinar, Dec. 8, 2015.

Lacroix, S. and F. Charette. 2013. Better planning with LiDARenhanced forest inventory. FPInnovations Advantage 14(1).

MacAfee, K.H. 2015. Working together to reach forest practitioners. For. Chron. 91(4): 211-212.

Meade, M. 2014. The necessary tools, the Canadian Institute of Forestry's electronic lecture series. In Success Stories from Canadian Forests, pp 24-25. CIF/IFC.

Moulton, T. 2013. Industry perspective-better forest management decisions using EFI/LiDAR [online].CIF workshop, March 27, 2013, Corner Brooke, Nfld. Available from: http://www.cif-ifc.org/ wp-content/uploads/2014/05/Moulton_NLEFI.pdf [accessed on June 16, 2016].

Parliament of Canada. 2015. Evidence Thursday February 26, 2015. House of Commons, Standing Committee on Natural Resources.Available from: http://www.parl.gc.ca/HousePublica- tions $/$ Publication.aspx ? DocId $=7861684 \&$ Language $=E \&$ Mode $=1$ [accessed on June 16, 2016]

Pitt, D. 2015. Remote sensing for enhanced forest biometric and ground surface information; two examples of Canadian companies striving for precision forestry [online].Robotics in the Forest Workshop, Montreal, QC, April 21, 2015. Available from: http://fmtc.fpinnovations.ca/blog/wp-content/uploads/2015/05/Doug-PittCWFC.pdf[accessed on June 16, 2016].

Pitt, D. 2016. Cross Canada check-up [online]. Available from: https://www.cif-ifc.org/wp-content/uploads/2016/02/EFI-CrossCountry-update-poster.pdf[accessed on June 16, 2016].

Pitt, D. and J. Pineau. 2009. Forest inventory research at the Canadian Wood Fibre Centre: Notes from a research coordination workshop, June 3-4, 2009, Pointe Claire, QC. For. Chron. 85(6): 859-869. Renslow, M., P. Greenfield and T. Guay. 2000. Evaluation of multireturn LiDAR for forestry applications. U.S. For. Serv. Project Report RSAC-2060/4810-LSP-0001-RPT1. Available from: http://www. ndep.gov/USDAFS_LIDAR.pdf [accessed on June 16, 2016].

Rogers, E.M. 2003. Diffusion of innovation. $5^{\text {th }}$ Edition.Free Press. Smith, G.K.M., J.F. Pineau and W.F. Bell. 2008. Knowledge transfer and extension in the Canadian Ecology Centre - Forestry Research Partnership: From awareness to uptake. For. Chron. 84(5): 748-755.

Vekeman, M. 2016. Shining a light on forests. In Success Stories from Canadian Forests, Volume 2, pp. 30-32. CIF-IFC.

Wang, S., S. Blurton, K.H. MacAfee and G.K.M. Smith. 2012. An impact assessment of four research projects of the Canadian Wood Fibre Centre. Nat. Res. Can., Can. Wood Fibre Ctr., Ottawa, On.

White, J.C., M.A. Wulder, A.Varhola, M. Vastaranta, N.C. Coops, B.D. Cook, D. Pitt and M. Woods. 2013. A best practices guide for generating forest inventory attributes from airborne laser scanning data using the area-based approach. Info. Rpt. FI-X-10, Nat. Res. Can., Can. For. Serv. Can. Wood Fibre Ctr., Pac. For. Ctr., Victoria, BC.

Woods, M., D. Pitt, M. Penner, K. Lim, D. Nesbitt, D. Etheridge and P. Treitz. 2011. Operational implementation of a LiDAR inventory in boreal Ontario. Forest. Chron. 87(4): 512-528.

Wulder, M.A., C.W. Bater, N.C. Coops, T. Hilker and J.C. White. 2008. The role of LiDAR in sustainable forest management. Forest. Chron. 84(6): 807-826. 